\title{
FATAL POLYARTERITIS PRESENTING AS ASYMMETRICAL PERIPHERAL GANGRENE*
}

\author{
BY
}

\author{
M. K. KEECH AND H. E. PURO \\ From the Departments of Medicine and Pathology, Wayne State University College of Medicine, \\ and the Detroit Receiving Hospital, Detroit, Michigan
}

Peripheral gangrene is one of the rarest presenting features in polyarteritis nodosa. A man with paralysed right upper and left lower limbs following poliomyelitis in infancy was admitted to hospital with supraventricular tachycardia and peripheral gangrene in the non-involved extremities. In an attempt to relieve the severe foot pain following an exacerbation of the arteritis, intermittent epidural injections of xylocaine were given via an indwelling catheter. Autopsy revealed widespread vascular involvement with multiple infarctions of the viscera, these symptoms having been masked during life by steroid therapy.

\section{Case Report}

A 39-year-old unmarried draughtsman was admitted in April, 1963, during an attack of supraventricular tachycardia. Poliomyelitis at age 6 or 7 months had caused residual paralysis of the right arm and left leg. 8 years before admission he had undergone surgical correction of a deformity of the left foot. He had been admitted to hospital on three occasions for delirium tremens, had occasional bouts of epistaxis, and was subiect to depression and suicidal tendencies. He had lost $22 \mathrm{lb}$. in weight during the past year. His mother had died of tuberculosis, his father was alive with hypertension, and an older brother had diabetes and "mental illness".

The present illness began 10 weeks before admission when he noticed stiffness of both knees followed by paraesthesiae in both legs and feet with difficulty in walking due to loss of sensation in the feet. This was accompanied by loss of appetite, general weakness, and pain, tingling and numbness of the fingertips of the left hand. This loss of manual dexterity led to his discharge from his job because he could no longer perform his duties as a draughtsman. "Black and blue spots" developed 2 weeks before admission on the toes of the right foot, one week before admission over the sacral area, and 3 days

* Supported by U.S. Public Health Service Training Grant TI AM 5141 , and the Michigan Chapter of the Arthritis and Rheumatism Foundation. before admission over the distal segments of the first second, and third fingers of the left hand; 2 days before admission the left testicle became tender and swollen.

Examination.-He was a thin, anxious, white male with a rapid pulse. An electrocardiogram showed supraventricular tachycardia of $180-190$. This did not respond to carotid massage, Valsalva's manoeuvre, gagging, eyeball pressure or vasoxyl, so he was admitted to the ward, given aramine, and slowly digitalized.

Physical Examination.-Blood pressure 122/80; temperature $101^{\circ} \mathrm{F}$.; lungs clear.

No cardiomegaly, murmurs, or friction rubs were found. The right testicle measured $1 \times 2 \mathrm{~cm}$. and not tender, and the left $4 \times 4 \mathrm{~cm}$. and very tender.

There was atrophy of the right arm, shoulder-girdle muscles, and pectoralis major, and a blotchy, purpleblack rash on the distal segments of the left first, second, and third fingers (Fig. 1).

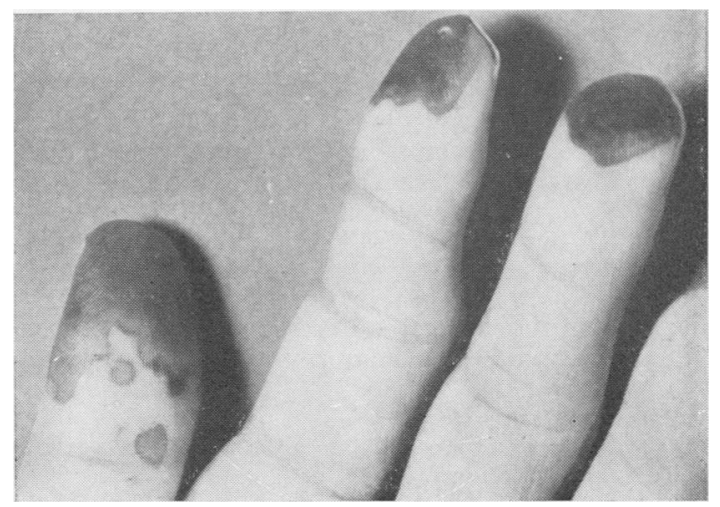

Fig. 1.-Gangrenous lesions of left thumb, index, and middle fingers on April 29.

The left leg was atrophied with some purple discoloration over the left lateral malleolus and toes. The right foot showed discolorations over the first and second toes with pes cavus deformity (Fig. $2 a$, overleaf). 


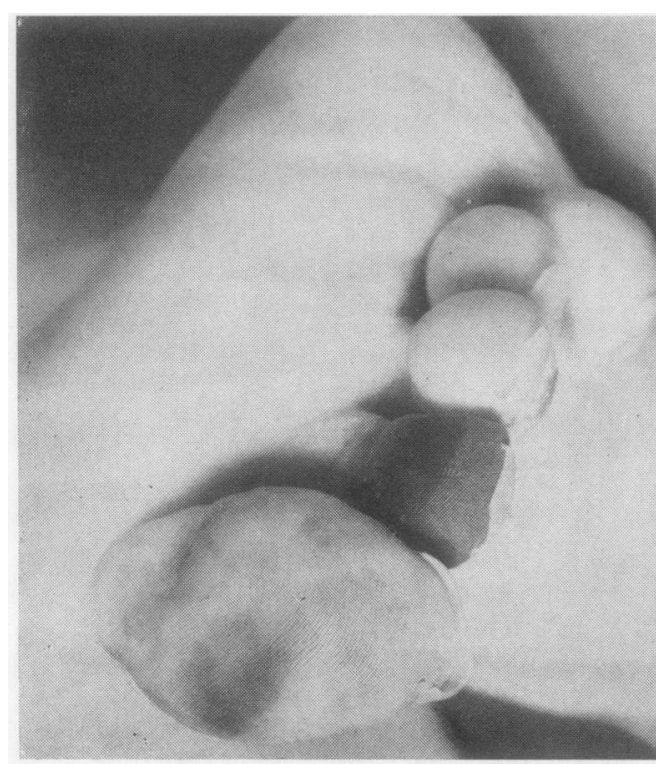

(a)

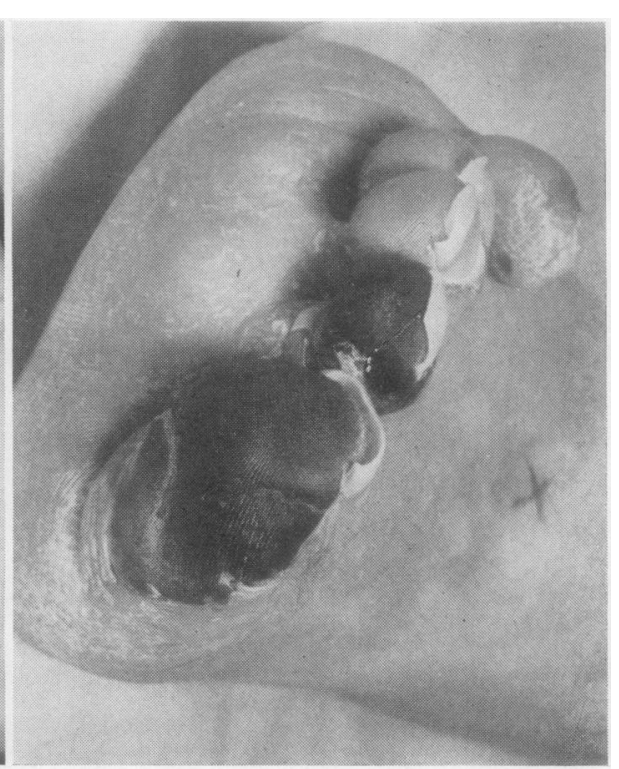

(b)

Fig. 2 (a).-Gangrenous lesions of right first and second toes on April 29. Note pes cavus deformity. (b).-Extension of gangrene to mid-tarsal level by June 6 .

Pedal pulses were palpable and full bilaterally. There was weakness of muscle power in the right arm and left leg with loss of deep tendon reflexes. Vibration sense and touch were intact.

\section{Laboratory Investigations}

BLOOD.-Haemoglobin 9.7 g.; white blood count 11,700; polymorphs 69 per cent.; lymphocytes 18 per cent.; eosinophils 10 per cent.; monocytes 3 per cent.; platelets $659,000 /$ c.mm.; reticulocytes $2 \cdot 3$ per cent.; erythrocyte sedimentation rate $98 \mathrm{~mm}$. (Westergren). Coombs, Kline, Kahn, cryoglobulins, FBS, SGOT, and serum creatinine all normal Five estimations BUN normal. Three lupus erythematosus preparations negative. The RA Hyland latex test was positive.

URINE.-Albuminuria, 12-18 white blood cells and 10-12 red blood cells.

SERUM ELECTROPHORESIS.-Total protein $6 \cdot 5 \mathrm{~g}$. per cent.; albumin $4 \cdot 13$; globulin $\alpha_{1}=0 \cdot 10, \alpha_{2}=0.31$, $\beta=0 \cdot 62, \gamma=1 \cdot 34$.

ELECTROCARDIOGRAM showed anomalous excitation (Wolf-Parkinson-White).

RADIOLOGY.-Chest $x$-ray revealed diminished muscle mass over right chest and osteoporosis of the right arm. Intravenous pyelogram and upper gastrointestinal tract series both normal.

BIOPSIES.-Skin from the buttock showed a small, necrotic ulcer. Skin over left elbow contained narrowed and obliterated arterioles with thickened, oedematousô $\overrightarrow{0}$ walls infiltrated with large numbers of polymorpho or nuclear leucocytes and a few eosinophils and lymphocō cytes. The specimen of gastrocnemius muscle did not? contain any large vessels, and the small vessels were normal.

Histological Diagnosis.-Acute vasculitis, compatible with polyarteritis nodcsa (Fig. 3, opposite).

Course.-The patient was treated with prednisolone, $50 \mathrm{mg}$. daily, ascorbic acid $300 \mathrm{mg}$. thiamine $300 \mathrm{mg}$., priscoline $75 \mathrm{mg}$., and digoxin. The gangrenous areas remained dry and uninfected and began to separate. However, he had an exacerbation of the arteritis on June 4 with the development of further gangrenous lesions on the right foot (Fig. 2b) and left hand. Prednisolone was increased to $80 \mathrm{mg}$. daily. Owing to the severe foot pain, an epidural block with 1 per cent. xylocaine was tried on June 5. The pain was relieved for 4 hours so the catheter was left in and the skin temperatures of both legs and feet recorded following further injections (Table, overleaf). The four readings on the control limb did not vary significantly. The first (lower leg) readings were almost always the same on both sides. At ankle level the temperature was $2-6^{\circ}$ lower on the affected side. At mid-tarsal level the readings were $8-10^{\circ}$ lower on the right. At the base of the great toe the temperature was $10-13^{\circ}$ lower on the affected side on June 5 and 6 , and $13^{\circ}$ lower on June 7 and 9. The highest reading for the affected great toe $\left(83.9^{\circ} \mathrm{F}\right.$.) was taken half an hour after $100 \mathrm{mg}$. epidural xylocaine. The lowest reading $\left(79.5^{\circ} \mathrm{F}\right.$.) 


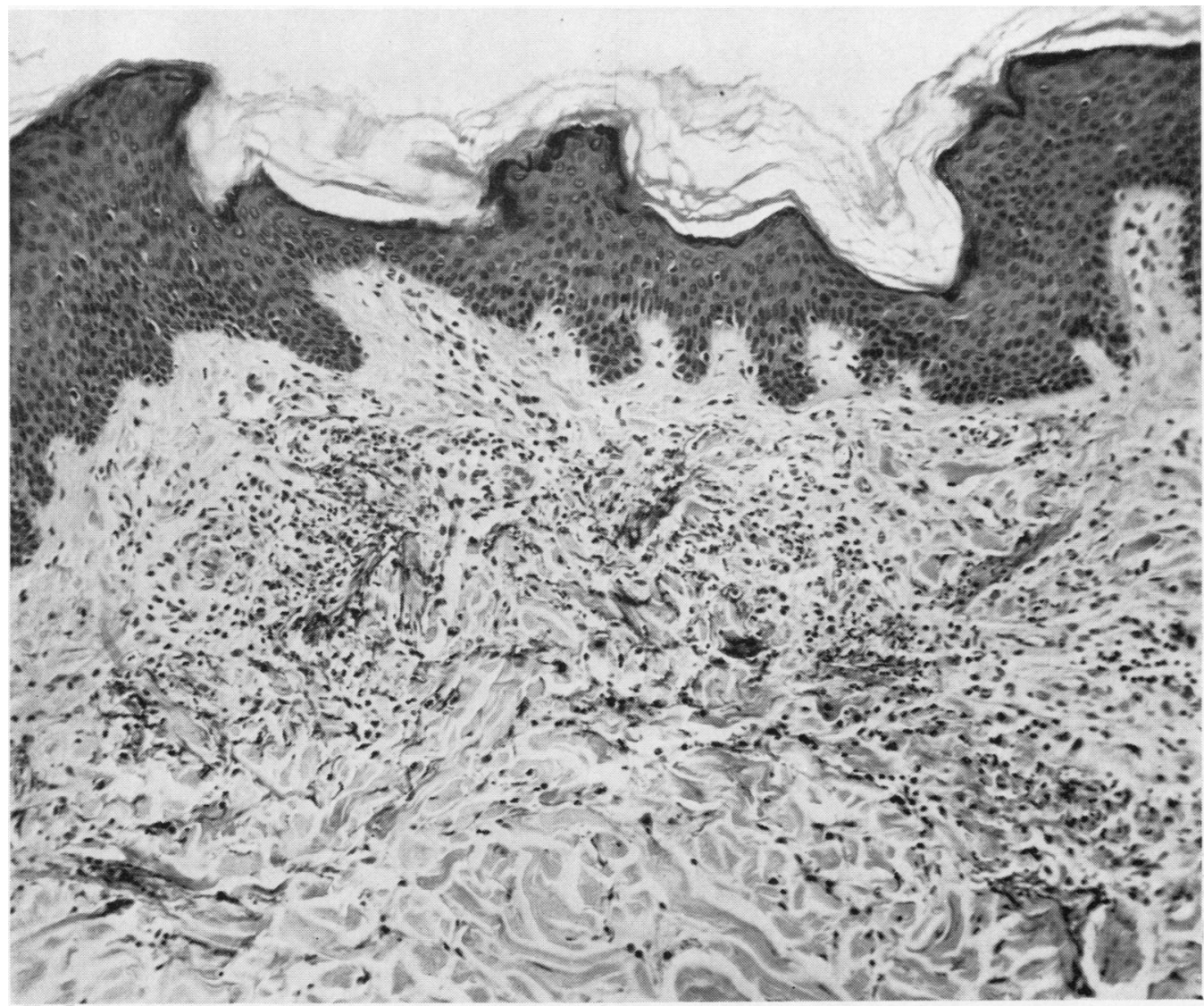

Fig. 3.-Skin biopsy showing arteritis. Haematoxylin and eosin. $\times 130$.

became constant on June 7 to June 9. Although the epidural xylocaine temporarily abolished the severe pain, only transient small increases in foot temperature were found. Fig. $2 a$ and $2 b$ illustrate the progressive changes from April 29 to June 6.

On June 19 he suddenly developed tachycardia, abdominal distention, vomiting, cyanosis, and shock, and expired.

Autopsy Report.-A poorly-developed, malnourished, markedly cachectic individual with atrophy of the right upper and left lower limbs and gangrenous areas on the right foot (Fig. 4, overleaf) and left hand.

Lungs.-There were multiple fibrous apical pleural adhesions and fibrocaseous lymphadenitis of the hilar and mediastinal lymph nodes, but no active tuberculous lesions were found. There was marked pulmonary oedema and passive congestion.

Heart.-This weighed $325 \mathrm{~g}$. and contained fresh infarctions measuring up to $2 \mathrm{~cm}$. in diameter in the posterior and lateral walls of the left ventricle, and extending into the posterior portion of the interventricular septum. The coronary arteries were patent and showed moderate atheroma, so that it was believed that the infarctions were due to occlusion of the smaller blood vessels. The heart valves and aorta were normal.

Abdomen.-The peritoneal cavity contained fibrinopurulent exudate, particularly around the acutelyinflamed gangrenous appendix and the gangrenous 
TABLE

SERIAL SKIN TEMPERATURES 5 MIN. AFTER REMOVAL. OF SOCKS AND SHEETS

\begin{tabular}{|c|c|c|c|c|c|c|}
\hline \multirow{2}{*}{ Date } & \multirow{2}{*}{ Time } & \multirow{2}{*}{ Epidural Xylocaine } & \multicolumn{4}{|c|}{ Temperature ( $\mathrm{F}$. ) } \\
\hline & & & \multicolumn{2}{|c|}{ Control Leg (Left) } & \multicolumn{2}{|c|}{ A ffected Leg (Right) } \\
\hline 5 June, 1963 & $\begin{array}{l}9.00 \text { a.m. } \\
1.45 \text { p.m. }\end{array}$ & $\begin{array}{l}290 \mathrm{mg} . \\
\text { No pain for } 4 \mathrm{hrs}\end{array}$ & $\begin{array}{l}(a) \\
(b) \\
(c) \\
(d)\end{array}$ & $\begin{array}{l}89 \cdot 8 \\
90 \cdot 8 \\
93 \cdot 0 \\
93 \cdot 1\end{array}$ & $\begin{array}{l}(a) \\
(b) \\
(c) \\
(d)\end{array}$ & $\begin{array}{l}89 \cdot 0 \\
84 \cdot 5 \\
83 \cdot 5 \\
81 \cdot 6\end{array}$ \\
\hline \multirow[t]{4}{*}{6 June, 1963} & $\begin{array}{l}12 \text { noon } \\
2.30 \text { p.m. }\end{array}$ & $100 \mathrm{mg}$. & $\begin{array}{l}\text { (a) } \\
\text { (b) } \\
\text { (d) }\end{array}$ & $\begin{array}{l}94 \cdot 5 \\
92 \cdot 8 \\
93 \cdot 8 \\
94 \cdot 4\end{array}$ & $\begin{array}{l}(a) \\
(b) \\
(c) \\
(d)\end{array}$ & $\begin{array}{l}91 \cdot 7 \\
89 \cdot 8 \\
84 \cdot 3 \\
81 \cdot 3\end{array}$ \\
\hline & 3.00 p.m. & No pain & $\begin{array}{l}(a) \\
(b) \\
(c) \\
(d)\end{array}$ & $\begin{array}{l}93 \cdot 2 \\
93 \cdot 1 \\
94 \cdot 1 \\
94 \cdot 4\end{array}$ & $\begin{array}{l}(a) \\
(b) \\
(c) \\
(d)\end{array}$ & $\begin{array}{l}93 \cdot 5 \\
91 \cdot 8 \\
86 \cdot 0 \\
83 \cdot 9\end{array}$ \\
\hline & 6.15 p.m. & & $\begin{array}{l}(a) \\
(b) \\
(c) \\
(d)\end{array}$ & $\begin{array}{l}90 \cdot 2 \\
91 \cdot 0 \\
93 \cdot 4 \\
93 \cdot 6\end{array}$ & $\begin{array}{l}(a) \\
(b) \\
(c) \\
(d)\end{array}$ & $\begin{array}{l}91 \cdot 5 \\
88 \cdot 8 \\
84 \cdot 4 \\
82 \cdot 1\end{array}$ \\
\hline & $\begin{array}{l}6.20 \text { p.m. } \\
6.30 \text { p.m. }\end{array}$ & $40 \mathrm{mg}$. & $\begin{array}{l}(a) \\
(b) \\
(c) \\
(d)\end{array}$ & $\begin{array}{l}90 \cdot 5 \\
91 \cdot 2 \\
93 \cdot 1 \\
94 \cdot 4\end{array}$ & $\begin{array}{l}(a) \\
(b) \\
(c) \\
(d)\end{array}$ & $\begin{array}{l}89 \cdot 5 \\
87 \cdot 9 \\
84 \cdot 2 \\
82 \cdot 3\end{array}$ \\
\hline 7 June, 1963 & 9.00 a.m. & $40 \mathrm{mg}$ & $\begin{array}{l}(a) \\
(b) \\
(c) \\
(d)\end{array}$ & $\begin{array}{l}90 \cdot 5 \\
91 \cdot 0 \\
93 \cdot 0 \\
93 \cdot 0\end{array}$ & $\begin{array}{l}(a) \\
(b) \\
(c) \\
(d)\end{array}$ & $\begin{array}{l}91 \cdot 5 \\
88 \cdot 0 \\
83 \cdot 0 \\
79 \cdot 5\end{array}$ \\
\hline 8 June, 1963 & 10.45 a.m. & & $\begin{array}{l}(a) \\
(b) \\
(c) \\
(d)\end{array}$ & $\begin{array}{l}88 \cdot 6 \\
89 \cdot 4 \\
92 \cdot 0 \\
92 \cdot 6\end{array}$ & $\begin{array}{l}(a) \\
(b) \\
(c) \\
(d)\end{array}$ & $\begin{array}{l}92 \cdot 4 \\
89 \cdot 9 \\
82 \cdot 3 \\
79 \cdot 6\end{array}$ \\
\hline 9 June, 1963 & 9.15 a.m. & & $\begin{array}{l}\text { (a) } \\
(b) \\
(c) \\
(d)\end{array}$ & $\begin{array}{l}89 \cdot 5 \\
89 \cdot 5 \\
92 \cdot 0 \\
93 \cdot 0\end{array}$ & $\begin{array}{l}(a) \\
(b) \\
(c) \\
(d)\end{array}$ & $\begin{array}{l}89 \cdot 0 \\
89 \cdot 0 \\
83 \cdot 5 \\
79 \cdot 5\end{array}$ \\
\hline
\end{tabular}

(a) $12 \mathrm{~cm}$. above lateral malleolus; $(b)$ Dorsum level of lateral malleolus; $(c)$ mid-tarsal level; $(d)$ base of great toe.

The control (left) leg was paralysed by polio in infancy with pes cavus deformity. Measurements taken on a Tele-Thermometer, Model 43 TA, Yellow Springs Instrument Co., Inc. Note that Fig. $2 a$ and $b$ were taken on April 29 and June 6 respectively.

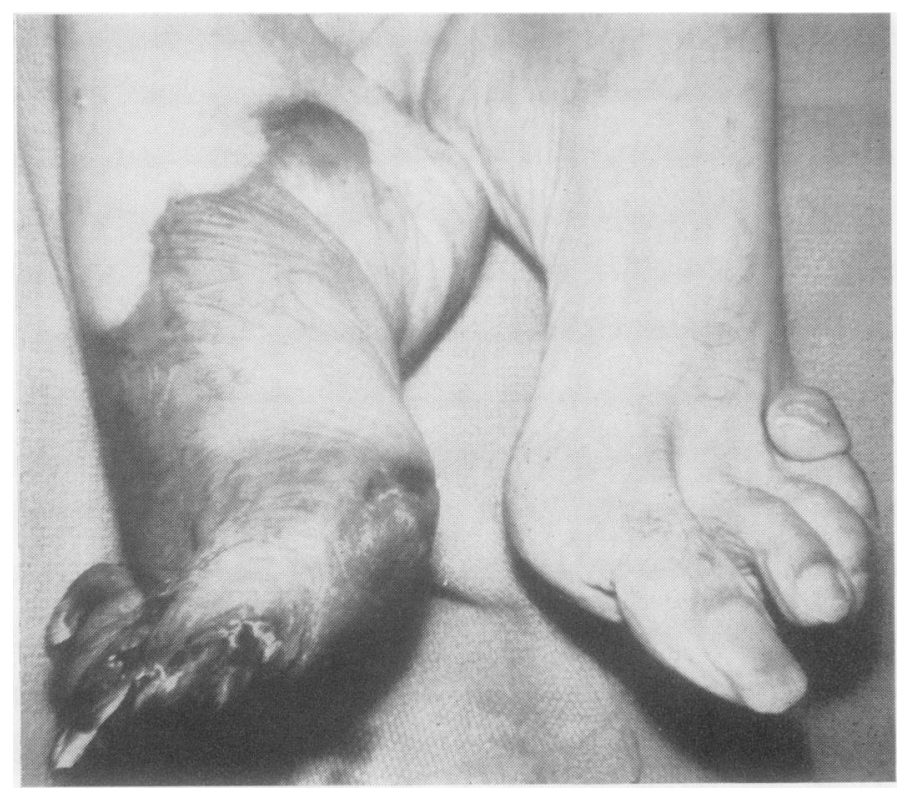

sigmoid colon, and in the lesser omental sac. There were multiple areas of infarction involving both large and small bowel, and the abdominal lymph nodes were enlarged and oedematous. The spleen was very soft and friable with numerous fibrous adhesions over the serosal surface. The liver and pancreas were congested. The adrenal glands were macroscopically normal. Both kidneys were small, each weighing 120 g., and showing fresh cortical infarcts, with scarring from old infarcts on the right. The right testis was unusually small and atrophic; the left appeared normal.

Brain.-This weighed $1,500 \mathrm{~g}$. with no macroscopic abnormality.

\section{Anatomical Diagnosis}

(1) Polyarteritis nodosa causing:

(a) Multiple vascular occlusions,

Fig. 4.-Post mortem appearance of feet on June 20. 
resulting in infarcts of the large and small bowel, the heart, and the kidneys;

(b) Left ventricular heart failure, causing severe pulmonary oedema and congestion;

(c) Generalized purulent peritonitis due to an acute, gangrenous appendix;

(d) Gangrene of the right foot and thumb and fingers of the left hand.

(2) Healed pulmonary tuberculosis with multiple apical pleural adhesions and fibrocaseous lymphadenitis of the hilar and mediastinal lymph nodes

\section{Microscopic Findings}

Heart.-Sections of the myocardium showed numerous small infarcts of varying age. Some of these were very early, with degeneration of the myocardial fibres and occasional polymorphonuclear leucocytes (PMN). In others the fibres were partially removed and associated with a mononuclear cell infiltrate. Some of the small and medium-sized arteries in the myocardium exhibited necrosis and inflammatory infiltrate in the wall. One medium-sized artery in the subepicardial region was completely occluded with partially organizing thrombus.

Lungs. - There was moderate oedema throughout both lungs and marked passive congestion. In some areas there was a moderate $\mathbf{P M N}$ infiltrate in the alveolar septa. There were some haemosiderin-containing macrophages in the alveoli and occasional small, fibrous scars in the lung parenchyma.

Spleen.-Sections revealed a few, small, recent infarcts. Some of the small arteries were occluded by thrombus and others contained inflammatory infiltrate in the wall.

Pancreas and Adrenal Glands.-These organs showed no special lesions, apart from various stages of necrosis

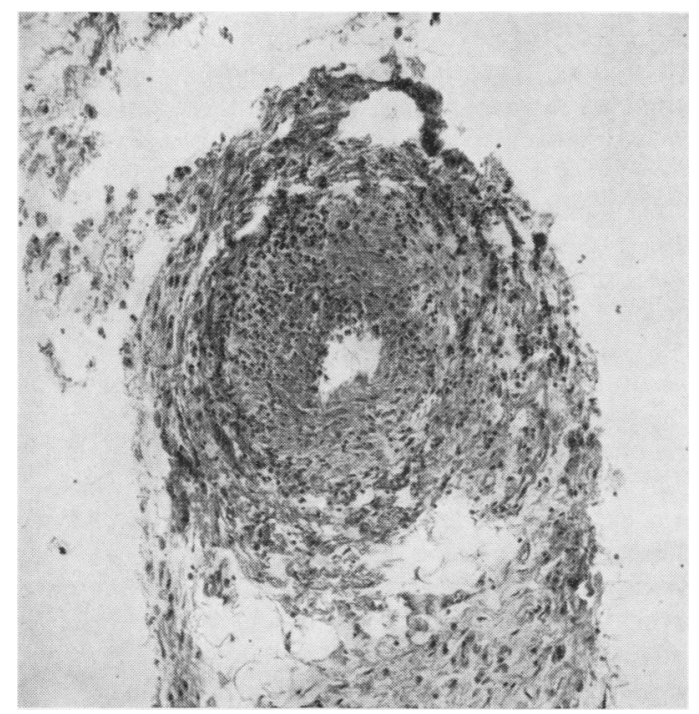

Fig. 5.-Acute arteritis with fibrinoid necrosis in the peri-adrenal fat. Haematoxylin and eosin. $\times 90$. and thrombosis in the peripheral arteries. Some of the peri-adrenal arteries were thrombosed and others were severely involved with polyarteritis nodosa (Figs 5 and 6).

Kidneys.-Both kidneys showed a similar pattern with multiple cortical scars and infarcts throughout. Many of the small and medium-sized arteries and occasional arterioles exhibited complete destruction of the wall with numerous inflammatory cells of various types and some fibrinous deposit in the areas they supplied. In some of the small arteries there was moderate proliferation of the endothelium causing occlusion of the vessel. Occasional glomeruli exhibited fibrinoid necrosis (Fig. 7, overleaf). Some of the larger arteries also showed inflammatory infiltrate in the wall with thrombus formation as well as branches of the larger renal veins, which were completely occluded with recent thrombus.

Oesophagus.-The vessels were severely involved with polyarteritis nodosa and some were thrombosed.

Intestinal Tract.-Numerous small infarcts associated with arteries showed arteritis and thrombosis. The appendix exhibited the picture of gangrenous appendicitis, consisting of ischaemic necrosis and inflammatory reaction.

Testes.-The left showed extensive infarction, only the outlines of the usual tubules remaining. No other type of reaction was seen.

Liver, Stomach, Aorta, and Prostate Gland.-No specific histological abnormalities.

Brain and Spinal Cord.-Right anterior horn atrophy in the cervical spinal cord and periarteritis in the dorsal root ganglion.

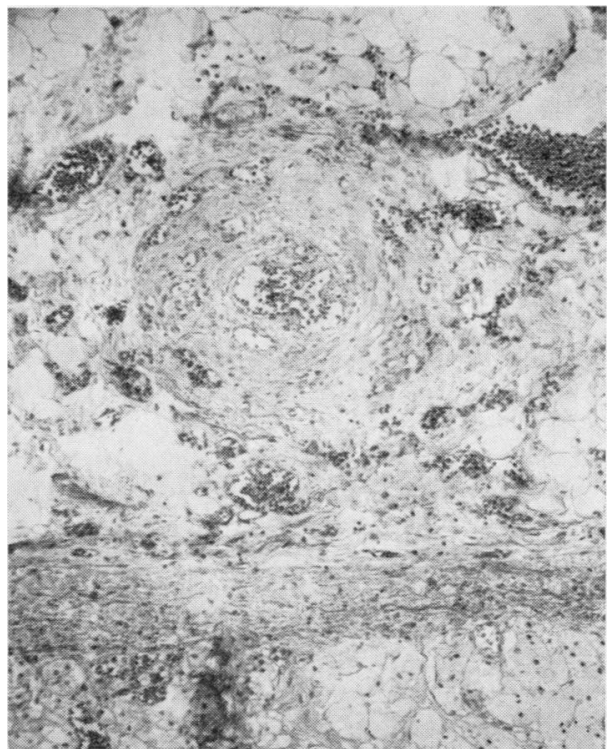

Fig. 6.-Healed arteritis in peri-adrenal fat. Haematoxylin and eosin. $\times 90$. 


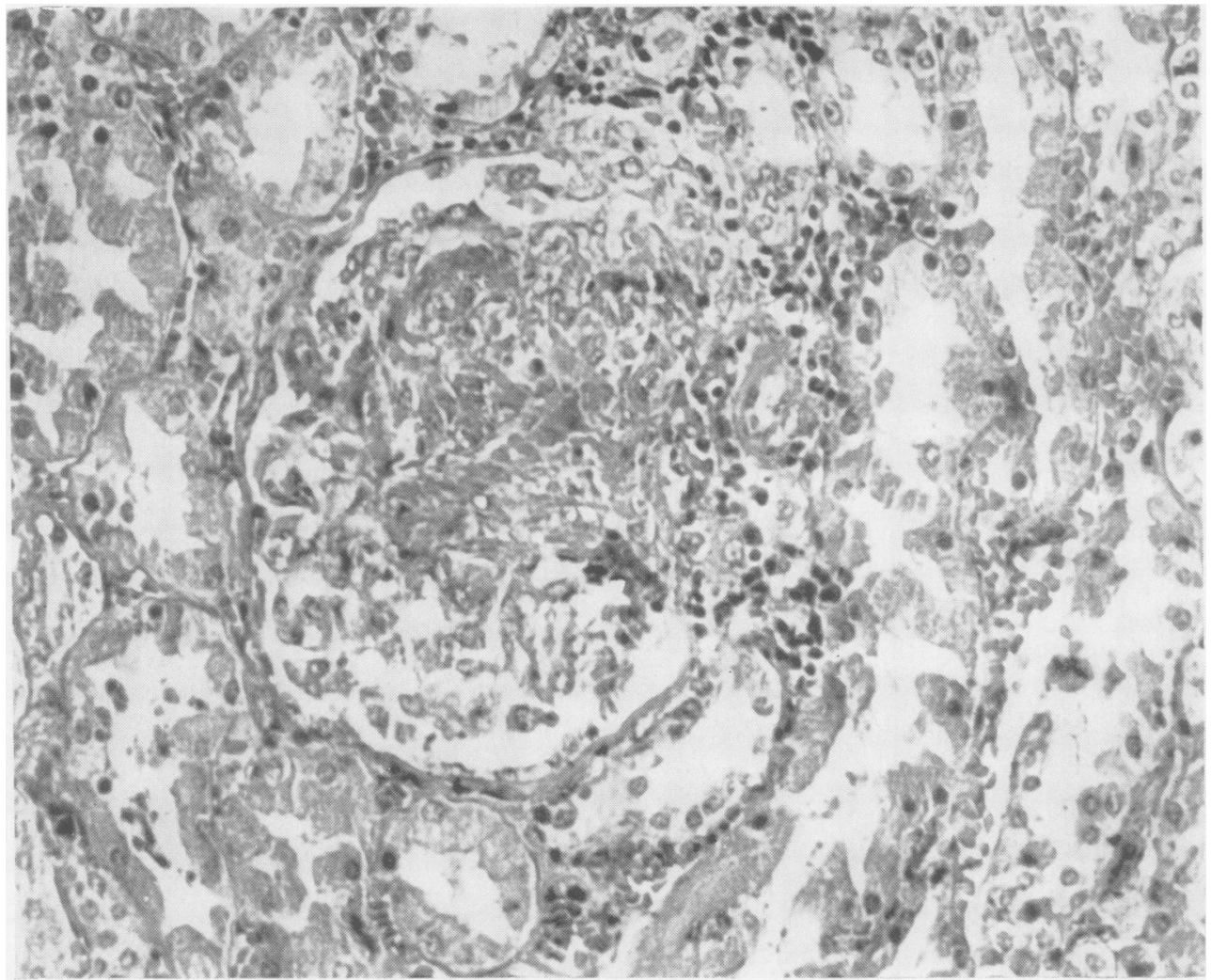

Fig. 7.-Kidney glomerulus showing acute fibrinoid necrosis. Haematoxylin and eosin. $\times 240$.

\section{Discussion}

Our case falls into the group classified by Rose as polyarteritis nodosa without lung involvement (Rose, 1957). The typical features include the age and sex of the patient, malaise, loss of weight, fever, anaemia, eosinophilia, raised sedimentation rate, renal and gastrointestinal involvement, congestive heart failure with myocardial infarctions, peripheral gangrene and a total course of 18 weeks (Blankenhorn and Knowles, 1954). Although fresh and old renal infarcts were found at autopsy, and persistent proteinuria and microscopic haematuria were present during life, there was no uraemia or hypertension. The findings were those described by Rose as renal polyarteritis, which he found in 39 of 52 cases with renal involvement. However, the specific form of glomerulitis described by him was not seen. We agree with the classification of Blankenhorn and Knowles as regards vessel size and evolution of the lesions, the patient exhibiting all stages of vascular inflammation and fibrosis.

Peripheral gangrene is a very rare presenting feature of this disease, especially in the absence of Raynaud's disease. Cooper (1961) reported the case of a railway porter, aged 60 , with sudden onset of symmetrical gangrene of the fingers (but not the thumbs) without a history of Raynaud's disease, who was successfully treated with anticoagulants and prednisolone. Similar features to our case were the predominant complaint of pain in the affected extremities, the laboratory findings, and the establishment of the diagnosis by skin biopsy. The dissimilarity resided in the symmetry of the lesions. The porter's occupation would have necessitated frequent, firm gripping movements of the fingers (carrying baggage, etc.) but not the thumbs. In our case only the active unparalysed limbs were affected. Thompson and Bywaters (1962) and Bywaters (1964) reported four cases of rheumatoid arthritis (RA) with hemiplegia which later developed arthritis almost entirely confined to the non-paralysed side, and reviewed the literature on a similar situation pertaining to Heberden's nodes (a genetically-determined form of osteo-arthritis). One of the 
four had radiological erosion in the active wrist but only osteoporosis of disuse on the inactive side. Brachial arteriograms demonstrated blocks and impaired pulp filling in both hands, but the vessels were of smaller calibre on the paralysed side; this indicated that a circulating agent, possibly the rheumatoid factor (RF), was partly responsible for the vascular changes. In a series of arteriograms on patients with rheumatoid arthritis and other disorders, three cases of polyarteritis nodosa showed a characteristic picture distinct from RA (Laws, Lillie, and Scott, 1963). The digital arteries were occluded distal to the palmar arch, their normal pattern being replaced by a network of irregular, tortuous, abnormal arteries. None of these patients had received steroid therapy. The abundance of these abnormal small vessels may explain the rarity of peripheral gangrene in polyarteritis.

A high correlation of rheumatoid arteritis with nodules and a positive test for RF was found in a series of 35 cases by Bywaters and Scott (1963). Nodules were only found on the unaffected and active side in patients with hemiplegia; "this is comparable with the well-known presence of elbow nodules on the opposite side to an affected shoulder". Stecher (1955) reported a patient with poliomyelitis who later developed Heberden's nodes in the normal but not in the paralysed hand. He states that in cases of cerebral palsy or peripheral nerve damage osteo-arthritis failed to develop in the area supplied by the affected nerve. This suggests that active movement is important in the genesis of joint changes (rheumatoid and osteo-arthritis) as well as in that of nodule formation. Sokoloff, McCluskey, and Bunim (1953) demonstrated that an arteritis similar to that found in the muscle and synovial membrane of rheumatoid patients is also the probable initial lesion in their early rheumatoid nodules.

Thus, it is possible that muscle activity of the extremities (in our case the fine co-ordinated movements of a one-handed draughtsman and full weight-bearing on the normal foot and leg) may favour the development of vasculitis in a predisposed subject.

The presence of RF in the blood may determine the vascular changes in rheumatoid arthritis (Bywaters, 1964; Epstein, 1957; Kunkel, 1960). In experimental animals, intimal localization of RF has been demonstrated (Hess and Ziff, 1960). RF was identified in experimentally-induced vascular lesions in rats given human serum that contained high titres of RF (Baum, Stastny, and Ziff, 1962). Macroglobulins may be dissociated in vitro into smaller globulin fragments by the action of sulphydryl reducing agents on the disulphide bonds (Deutsch and Morton, 1957). A fall in circulating macroglobulin levels has been reported in patients with Waldenström's macroglobulinaemia and cold agglutinin haemolytic anaemia after the administration of the thiol compound, penicillamine (Ritzman, Coleman, and Levin, 1960, 1961 ; Bloch, Prasad, Anastasi, and Briggs, 1960). RF is a macroglobulin with physical and chemical properties similar to Waldenström's macroglobulin. Jaffe (1964) reported clinical and serological improvement in a patient with rheumatoid arthritis and arteritis manifested by leg ulcers and gangrene. It is noteworthy that the lowest serum sulphhydryl cocnentrations were found in rheumatoid arthritis complicated by necrotizing arteritis, in active systemic lupus erythematosus (SLE) and polyarteritis nodosa (Lorber, Pearson, Meredith, and Gantz-Mandell, 1964). These levels corresponded to the values found in Waldenström's macroglobulinaemia. These low levels are presumed to be due to the dehydrogenation of the sulphhydryl groups leading to the formation of disulphide bonds that link the protein sub-units together to make the abnormal macroglobulin (Lorber and others, 1964). RF may be responsible for the vasculitis that occurs in some cases of connective tissue disease (Kunkel, 1960), either because of its physical properties (increased viscosity, cryo-precipitability, etc.) or because of its peculiar affinity for autologous tissues. RF has also been demonstrated in the synovial membranes, lymph nodes, skin, and other tissues of patients with rheumatoid arthritis (McCormick, 1963; Mellors, Nowoslawski, and Korngold, 1961; Mellors, Nowoslawski, Korngold, and Sengson, 1961; Ball, 1962; Bland and Clark, 1962; Rodnan, Eisenbeis, and Creighton, 1962), that is, at sites where lymphocytes and plasma cells are located. A careful immunocytochemical study of a patient with polyarteritis nodosa and a positive latex-fixation test revealed that cells in the spleen with the morphological characteristics of plasma cells, contained a 19S macroglobulin. Positive staining of these cells with aggregated fluorescein-labelled human gamma globulin suggested that they contained RF (Paronetto and Strauss, 1962). Our patient had a positive latex-fixation test and a gamma globulin at the upper limits of normal on serum protein electrophoresis (1.34 g. per cent.). Thus, in the light of the evidence presented, it would appear reasonable to give penicillamine a therapeutic trial in cases of polyarteritis with RF in an effort to reduce the likelihood of further exacerbations of the vasculitis. Prolonged treatment at $2 \mathrm{~g}$. daily in order to achieve a fall in circulating RF would be indicated, as emphasized 
by Jaffe (1964) in the management of rheumatoid arteritis

Various drugs have been related to the onset of vasculitis in polyarteritis, SLE, and thrombotic thrombocytopenic purpura, mainly the sulphonamides, penicillin, hydralazine, and anticonvulsants (Glaser, 1963; Symmers, 1962). Also, streptococcal infection may precede polyarteritis nodosa. Our patient gave no history of preceding infection and no known therapeutic antigen was administered in the hospital before the exacerbation of the arteritis on June 4, while he was taking $50 \mathrm{mg}$. prednisolone daily. The only substance that could possibly be incriminated was the local application of bacitracin ointment for the infected skin biopsy site over the left elbow.

Corticosteroid therapy is the recognized (and only) form of treatment at the present time for severe polyarteritis. However, the healing process in the vessels may produce further ischaemia and infarction of tissue despite satisfactory generalized responses (Glaser, 1963; Symmers and Litchfield, 1952). A long-term study of the effect of cortisone in polyarteritis showed that, although the treated group was superior to the untreated group at the end of one year, after 3 years this advantage had disappeared (M.R.C., 1957, 1960). Thus, cortisone may prolong life but does not produce a cure. It is well established that sudden corticosteroid withdrawal may produce an acute arteritis, for example in rheumatoid arthritis, SLE, or scleroderma (Symmers, 1962). The apparent increase in rheumatoid arteritis since the introduction of corticosteroids has led us to question the role of these drugs in the pathogenesis of vasculitis (Adler, Norcross, and Lockie, 1962; Fisher, 1957). However, sixteen of the 35 cases of rheumatoid arteritis reported by Bywaters and Scott (1963) had not had steroid therapy, and three other series were quoted in which the majority had not received steroids. The association with steroid therapy thus appeared to be secondary, since the more severe cases were given steroids. Fatal myocardial infarction following steroid administration to a patient with polyarteritis has been reported by Nachman (1961), who noted the occasional paradoxical adverse effects of steroids. However, as pointed out by Smyth (1964), "most would agree that steroid dosage should be lowered when a paradoxical adverse reaction is encountered ... (but) the final answer is not yet known".

In our patient the exacerbation of the arteritis was taken as an indication to increase the dose of prednisolone. We may have been at fault in this respect. Autopsy revealed old and fresh myocardial infarcts, the older lesions presumably having occurred 2 months before death during the first bout of tachycardia. In a study of 66 autopsies on polyarteritis nodosa, it was found that 41 had myocardial infarcts most of which were silent (Holsinger, Osmundson, and Edwards, 1962). In another series of thirty autopsies, 25 showed glomerular changes, and renal biopsy was suggested as the best method of establishing the diagnosis during life (Patalano and Sommers, 1961). Our previous experience would support this suggestion, as the kidney appears to be one of the most constantly and diffusely involved organs, whereas in the other tissues the lesions are more scattered.

\section{Summary}

A 39-year-old white male, with paralysed right upper and left lower limbs due to poliomyelitis in infancy, presented with a 10-week history of systemic symptoms and paraesthesiae of the left hand and both legs and feet, followed by peripheral gangrene in the unparalysed extremities and supraventricular tachycardia. He had been discharged from his job as a draughtsman owing to loss of dexterity in his left (unparalysed) hand. While on steroid therapy, a further exacerbation of the arteritis occurred and he expired during another bout of tachycardia, 18 weeks after the onset. Autopsy revealed widespread vessel involvement with multiple infarctions of the heart, intestine and kidneys, a acutely inflamed, gangrenous appendix and general $\Rightarrow$ ized peritonitis. During life the abdominal symptoms were masked by the steroid therapy. Possible reasons for the localization of the gangrene to the unparalysed extremities are discussed.

The literature on the rationale and use of sulphhydryl-reducing agents in diseases characterized by abnormal macroglobulins is reviewed.

We wish to thank Dr. P. C. Martineau for access to his biopsy and autopsy reports and for Figure 4, and the Department of Photography, headed by Mr. C. Pickard, for the illustrations.

\section{REFERENCES}

Adler, R. H., Norcross, B. M., and Lockie, L. M. (1962). J. Amer. med. Ass., 180, 922.

Ball, J. (1962). Ann. rheum. Dis., 21, 272.

Baum, J., Stastny, P., and Ziff, M. (1962). Arthr. and Rheum., 5, 101.

Bland, J. H., and Clark, L. G. (1962). Ibid., 5, 102.

Blankenhorn, M. A., and Knowles, H. C. (1954). Ann. intern. Med., 41, 887.

Bloch, H. S., Prasad, A., Anastasi, A., and Briggs, D. R. (1960). J. Lab. clin. Med., 56, 212.

Bywaters, E. G. L. (1964). Canad. med. Ass., J., 91, 606. and Scott, J. T. (1963). J. chron. Dis., 16, 905. 
Cooper, A. S. (1961). Guy's Hosp. Rep., 110, 110.

Deutsch, H. F., and Morton, J. I. (1957). Science, 125, 600.

Epstein, W. (1957). In "Serological Reactions of Rheumatoid Arthritis', ed. R. W. LamontHavers, p. 22. Arthritis and Rheumatism Foundation, New York.

Fisher, E. R. (1957). Amer. J. clin. Path., 27, 191.

Glaser, G. H. (1963). Med. Clin. N. Amer., 47, 1475.

Hess, E. V., and Ziff, M. (1960). Quoted by Odone, D. T., Wilson, A. F., and Engleman, E. P. in Bull. rheum. Dis., 11, 229.

Holsinger, D. R., Osmundson, P. J., and Edwards, J. E. (1962). Circulation, 25, 610.

Jaffe, I. A. (1964). Ann. intern. Med., 61, 556.

Kunkel, H. G. (1960). "Macroglobulins and High Molecular Weight Antibodies", in "The Plasma Proteins”, ed. F. W. Putnam, vol. 1, pp. 299, 302, 305. Academic Press, Inc., New York.

Laws, J. W., Lillie, J. G., and Scott, J. T. (1963). Brit. J. Radiol., 36, 477.

Lorber, A., Pearson, C. M., Meredith, W. L., and GantzMandell, L. E. (1964). Ann. intern. Med., 61, 423.

McCormick, J. N. (1963). Ann. rheum. Dis., 22, 1.

Medical Research Council (1957). Brit. med. J., 1, 608. (1960). Ibid., 1, 1399.

Mellors, R. C., Nowoslawski, A., and Korngold, L. (1961). Amer. J. Path., 39, 533.

,,-- , and Sengson, B. L. (1961). J. exp. Med., 113, 475.

Nachman, R. L. (1961). Amer. J. Cardiol., 7, 288.

Paronetto, F., and Strauss, L. (1962). Ann. intern. Med., 56, 289.

Patalano, V. J., and Sommers, S. C. (1961). Arch. Path., 72, 1 .

Ritzmann, S. E., Coleman, S. L., and Levin, W. C. (1960). J. clin. Invest., 39, 1330.

and Levin, W. C. (1961). J. Lab. clin. Med., 57, 718.

Rodnan, C. P., Eisenbeis, C. H. Jr., and Creighton, A. S. (1962). Arthr. and Rheum., 5, 316.

Rose, G. A. (1957). Brit. med. J., 2, 1148.

Smyth, C. J., and others (1964). Ann. intern. Med., Suppl. 6, pp. 44.

Sokoloff, L., McCluskey, R. T., and Bunim, J. J. (1953). Arch. Path., 55, 475.

Stecher, R. M. (1955). Ann. rheum. Dis., 14, 1.

Symmers, W. St. C. (1962). Proc. roy. Soc. Med., 55, 20.

- and Litchfield, J. A. (1952). Lancet, 2, 1193.

Thompson, M., and Bywaters, E. G. L. (1962). Ann. rheum. Dis., 21, 370.
Polyartérite fatale se présentant comme gangrène périphérique asymétrique.-Description clinique et anatomo-pathologique d'un cas

\section{RÉSUMÉ}

Un homme de race blanche, âgé de 39 ans, ayant des membres supérieur droit et inferieur gauche paralysés par la poliomyélite depuis l'enfance, s'est présenté avec des symptômes généraux et des paresthésies à la main gauche et aux deux jambes et pieds d'une durée de 10 semaines. Cela fut suivi d'une gangrène périphérique des membres non paralysés et d'une tachycardie supraventriculaire. On l'avait renvoyé de son travail de dessinateur parcequ'il avait perdu l'habilité de sa main gauche (non paralysée). Pendant la thérapie stéroïde il y eut une autre exacerbation de l'artérite et il mourut au bout d'une attaque de tachycardie 18 semaines après le début de la maladie. L'autopsie révéla des lésions vasculaires étendues, de nombreux infarctus du coeur, de l'intestin et des reins, l'appendice très inflammé et gangréneux et une péritonite généralisée. Avant la mort les symptômes abdominaux étaient masqués par la thérapie stéroïde. On discute les raisons possibles de la localisation de la gangrène aux membres non paralysés.

On discute la littérature et la raison de l'emploi des agents qui réduisent le sulphydryl dans les maladies caractérisées par des macroglobulines anormales.

Poliarteritis fatal presentándose como gangrena periférica asimétrica.-Relato clínico $y$ anatomo-patol gico de un caso

\section{SUMARIO}

Un hombre de raza blanca de 39 años, con el brazo derecho y la pierna izquierda paralizados por poliomielitis desde su infancia, se presentó con síntomas generales y parestesias en la mano izquierda y en ambos pies y piernas desde 10 semanas. Esto fué seguido de una gangrena periférica de las extremidades non-paralizadas y de una taquicardia supraventricular. El paciente había sido despedido de su trabajo de delineante por haber perdido la destreza de su mano izquierda (non-paralizada) Durante la terapia esteroide una exacerbación más de la arteritis y de la taquicardia se produjo y el enfermo falleciò 18 semanas después del comienzo de la enfermedad. La necropsia reveló lesiones vasculares extensas, infartos multiples del corazón, del intestino y de los riñones, el apéndice muy inflamado y gangrenoso y una peritonitis generalizada. Durante la vida la terapia esteroide encubría los síntomas abdominales. Se discuten las razones posibles de la localización de la gangrena en las extremidades non-paralizadas.

Se pasa revista a la literatura acerca del empleo de los agentes de reducción del sulfidril en enfermedades caracterizadas por macroglobulinas anormales. 